\title{
502 ティフューザポンプ軸系に作用する流体力に関する研究
}

\section{Unsteady Hydrodynamic Forces on Diffuser Pump Shaft}

\author{
○学 秋山 彰一 (九工大院) \\ 正 宮崎 康次（九工大院） \\ 正 塚本 實 (九工大院) \\ 学 稲田 和久 (九工大)
}

Shoichi AKIYAMA, Hiroshi Tsukamoto, Koji MIYAZAKI, Kazuhisa INADA

Key Words : Diffuser Pump, Diffuser vane, Rotor-Stator Interaction, Radial Fluid Force. Tip Clearance, Quasi-Steady

1. 緒害

近年,ボンブには, 高速・小型・軽量化が要求されている. しかし，ポンプの高速化には，振動・跬音等，設計・製作上 の課題が多い.軸系振動特性の予測を目的とした振動解析は 近年実用化されつつあるが, 遠心ポンプ, 特に案内羽根を有 したティフューザポンブ軸系に作用する流体加振力の定量 的大きさ，周波数特性等に関する知識は十分でない．また， ポンブ軸系に作用する流体力を静止系から考察する研究は 多数行われているか，回転系から扱う研究は少なく，また， ポンプ過渡運転時に作用する過渡流体力に関しても良く知 られていない。そこで本研究では, 形状の異なる 2 種類の羽 根車を使用し，供試ボンプの種々のバラメータが軸系に作用 する流体力に及ほす影響を明らかにした。また，ポンプ急始 動・急停止の運転条件で流体力を測定し, 過渡流体力に及ほ すパラメータを加速・減速時間と関連つけて解析し，流体力 の準定常值との違いを明らかにした。

\section{2. 実験装置及び実験方法}

困 1 に実験装置全体図及ひ計測系を示す。

2.1 ポンブ系

- 遠心羽根車: 羽根枚数 $Z_{i}=6$, 比速度 $202\left[\mathrm{~min}^{-1}, \mathrm{~m}^{3} / \mathrm{min}, \mathrm{m}\right]$, クロースド及びオープンインペラの 2 種類を使用.

・ティフューザ及びケーシング : 羽根枚数の影響を調へるた めティフューザ羽根枚数可変 $Z_{d}=0 \sim 7$ (ケーシングから着 脱可能）。両吐出し円形ケーシングを使用.

\section{2 湘定量及び計測系}

- 吸込圧·吐出し圧 $P_{s}, P_{d}$ : 半導体式圧力変換器により計測.

・回転数 $N$ ：供試ポンブ駆動には三相誘導電動機を用いイン バータによる周波数制御によって任意回転数及び任意の 回転加速・減速での運転が可能. 東と電磁ビックアッブ の組み合わせで発生するパルス信号から計測。

・流量 $Q$ : 交流励磁方式の電磁流量計で測定.

- 非定常流体力 $F_{x}, F_{y}$ : 図 2 に示すように, 主軸に歪ゲージ による2軸力センサを設け, $x, y$ の 2 つの方向成分で計測.

測定された流体力は定常と変動成分に分けて分析した。

\section{3 定常運転時の流体力测定実跧方法}

供試ポンプ回転数を一定に保ち，仕切弁を全開状態から全 閉状態まで変化させ, 吐出し弁開度, ティフューザ羽根枚数 を種々組み合わせて，クロースドまたはオープンインペラで 各測定量を測定した.オープンインペラにおいては, シュラ ウド面とケーシングとのスラスト方向隙間 (翼先端腙間)を $0.5[\mathrm{~mm}]$ で実験を行った。

2.4 ボンプ急始動・急停止時の流体力測定実鍳方法

ティフューザ羽根枚数 $\mathrm{Z}_{\mathrm{d}}=5$ で仕切弁開度を固定して吐出 し流量を一定にし，最終及び初期回転数 $N=1750\left[\mathrm{~min}^{-1}\right]$ でイ ンバータにより強制的にモータを加速・減速させ，加速時間 $T_{n a} \cdot$ 減速時間 $T_{n d}$ をそれそれ変化させて実験を行った。表 1 , 2 に代表的な実験条件を示す。
Table 1 List of test conditions at pump start-up

\begin{tabular}{cccc}
\hline Case No. & $T_{\text {m }}$ & $N T_{\text {na }}$ & $\phi / \phi_{r}$ \\
\hline PA-1 & 0.07 & 2.04 & 1.0 \\
PA-1 & 0.21 & 6.12 & 1.0 \\
\hline
\end{tabular}

Table 2 List of test conditions at pump shutdown

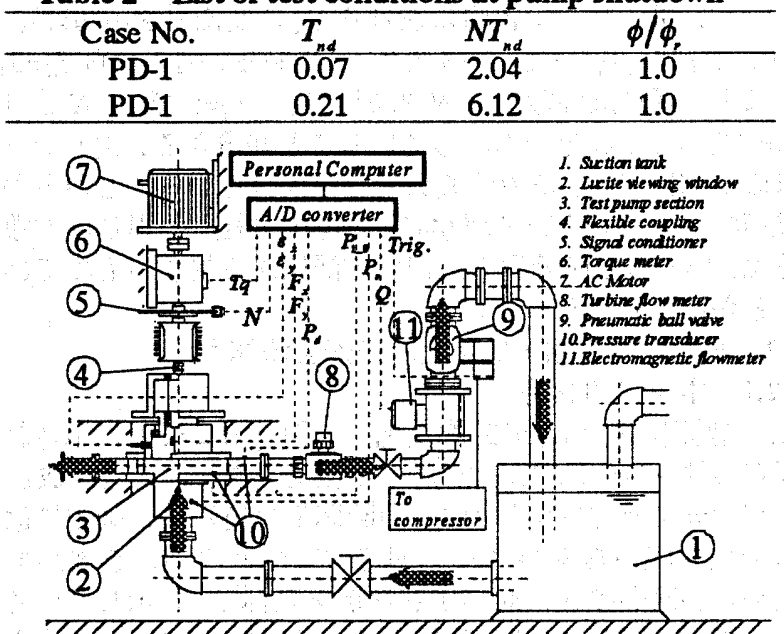

Fig.1 Schematic view of test rig and instrumentation system

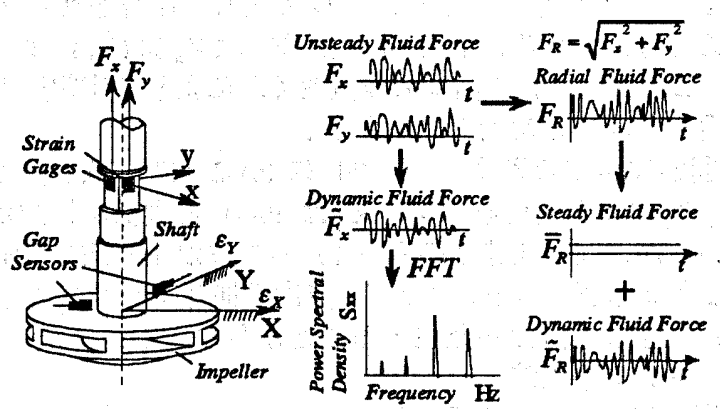

Fig.2 Schematics of fluid force measurement system and data processing of unsteady fiuid force signal

\section{3. 実験結果及ひ考察}

\section{1 定常運転時の軸系に作用する非定常流体力}

3.1.1 非定常流体力 図3に設計流量で両インペラ使用時 の無次元変動流体力 $\tilde{K}_{x}$ の瞬時波形を示す. 横軸にインペラ か 1 回転する時間を 1 とした無次元時間 $N t$ を示す. 図 3 か らどちらのインペラでも $Z_{d}=5,7$ に比べ $Z_{d}=0,6$ では特定の 周波数成分で大きい変動が見られる. 図 4 に両インベラの流 量に対する無次元半径方向流体力 $\bar{K}_{R}$ を示す. 横軸は流量係 数 $\phi$ である. 図 4 からどちらのインぺラでも $Z_{d}=0,6$ に比べ $Z_{d}=5,7$ で $\bar{K}_{R}$ が大きい.これは $Z_{d}=0$ では動静翼干渉がなく， $Z_{d}=6$ では羽根に作用する流体力が周方向対称になり相殺さ れるためと考えられる. また図3からオープンインペラはク ロースドインベラに比べて流体力の変動が小さいことが分 かる.これは翼先端隙間での漏れによる二次流れの影響を受 けているためと考えられる.

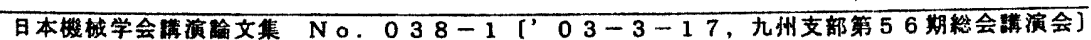




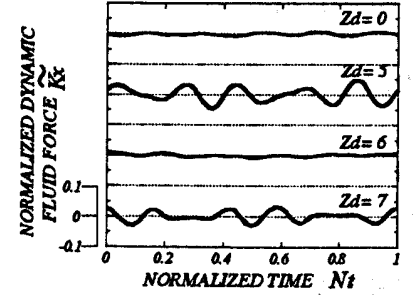

(a) closed impeller (b) open impeller

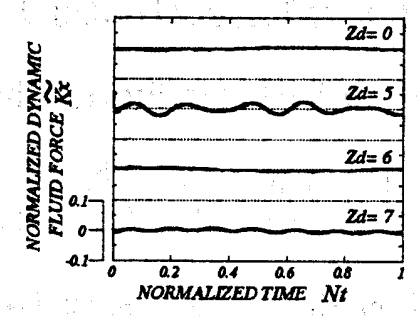

Fig.3 Time histories of normalized dynamic fluid force for various diffuser vane's number ( $\mathrm{N}=1750\left[\mathrm{~min}^{-1}\right]$, design flow rate)

3.1.2 変動流体力周波数解析 羽根車に作用する㚆動流 体力の周波数成分を調べるために周波数解析を行った. 図 5, 6 に $\mathrm{x}$ 方向の無次元変動流体力のパワースペクトル密度 $S_{x x}$ を示す.横軸は周波数 $f$ を回転数 $N$ で除した無次元周波数 $f / N$

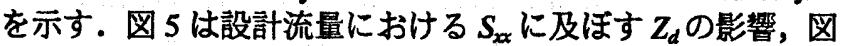
6 は流量比 $\phi / \phi r$ 毎の $Z_{d}=5$ での $S_{x x}$ である. 図 5 から $Z_{d}=5,7$ では羽根通過周波数成分 $N Z_{d}$ 成分及び $Z_{d}=5$ では $7 N$ 成分, $Z_{d}=7$ では $5 N$ 成分が卓越していることが分かる. 図 6 から流 量の増加に伴い, 卓越周波数成分が大きくなることが分かる. 幾何学モテルを用いて理論的に考察した結果, 卓越周波数成 分は、いずれも動静翼の幾何学的関係から生ずるものである ことが明らかになった。

3.2 ポンプ急始動・急停止時の過洨流体力

3.2.1 ポンブ始動時

(a) 過湾流体力 $K_{R}$ の時間変化 図 7(a)に表 1 に示される 運転条件 PA-1 $\left(N T_{n a}=2.04\right)$ での流量係数 $\phi$, 掦程係数 $\psi$ 及 び無次元半径方向流体力 $K_{R}$ の時間変化を示す. 図中には定 常特性曲線から期待される準定常変化との違いを検討する ために各瞬間の $\phi$ に対応する準定常值 $\left(\bar{K}_{R}\right)_{s}$ を示している. 図から,Aの部分では過渡流体力 $K_{R}$ は $\left(\bar{K}_{R}\right)_{s}$ に比べて大きい。 これはポンプ始動によるインパルス圧の影響を受けてい るためと考えられる. また B の部分では $K_{R}$ は $\left(\bar{K}_{R}\right)_{S}$ より小 さい.これは翼まわり循環の成長おくれにより準定常圧力上 界が得られないためと考えられる.

(b) 回転加速率の影敕 図 7(b)に PA-2 $\left(N T_{n a}=6.12\right)$ での $\phi, \psi, K_{R}$ の時間変化を示す. $K_{R}$ は PA-1 と同様な特徴が現 れているが, 回転加速率の高い PA-1 の方がより激しい流体 力の変化が確認できる. 従って, 無次元加速時間 $N T_{n a}$ が小さ いほど大きな流体力が発生することが分かった.

3.2.2 ポンプ停止時

(a) 過洨流体力 $K_{R}$ の時間変化 図 $7(\mathrm{c})$ にPD-1 $\left(N T_{n d}=2.04\right)$ での $\phi, \psi, K_{R}$ の時間変化を示す. C の部分では過渡流体力 $K_{R}$ は $\left(\bar{K}_{R}\right)_{S}$ に比べて小さい.これは停止によるインパルス圧 力の影響を受けているためと考えられる.また D の部分では $K_{R}$ は $\left(\bar{K}_{R}\right)_{s}$ より大きくなっている.これは流体の慣性の影響 を受けているためと考えられる。

(b) 回転減速率の影贈 図 7(d)に PD-2 $\left(N T_{n d}=6.12\right)$ での $\phi, \psi, K_{R}$ の時間変化を示す. $K_{R}$ は PD-1 と同様な特徵が現 れているが, 回転減速率の高い PD-1 の方がより激しい流体 力の変化が確認できる. 従って, 無次元減速時間 $N T_{n d}$ が小 さいほど流体力が準定常値から逸脱することが分かった。

\section{4. 結㝘}

定常運転時の流体力実験から以下のことがわかった.

（1）動静翼の羽根枚数に公䄪数がないとき, 定常流体力及 び変動流体力振幅が大きくなる.

(2) 翼先端隙間があると変動流体力は大きくなる.

（3）変動流体力は流量に依存する.

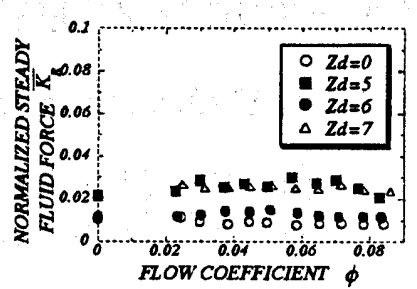

(a) closed impeller

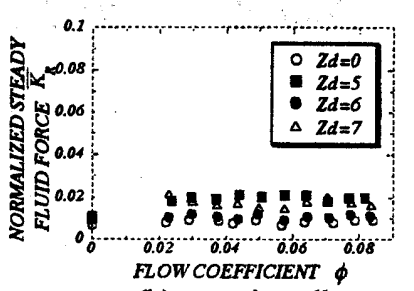

(b) open impeller
Fig.4 Normalized steady fluid force for various

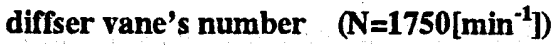

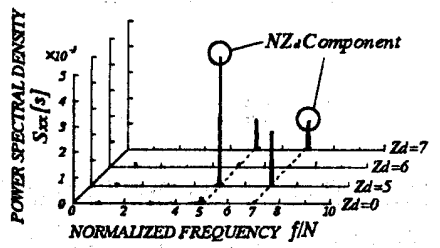

Fig.5 Power spectral density of dynamic fluid force for various diffuser vane's number

( $\mathrm{N}=1750\left[\mathrm{~min}^{-1}\right]$, rated condition)

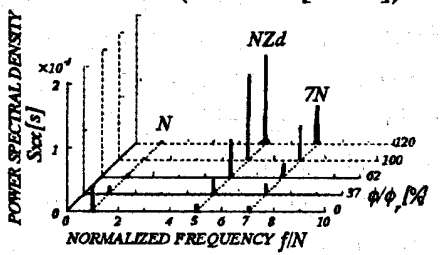

(a) closed impeller

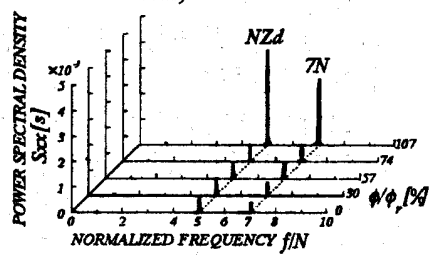

(b) open impeller
Fig.6 Power spectral density of dynamic fluid force $\left(\mathbf{N}=1750\left[\mathrm{~min}^{-1}\right], Z_{d}=5\right)$

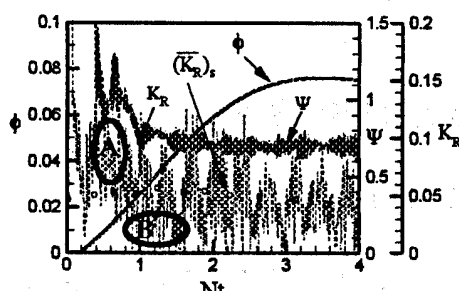

(a) ${ }^{\mathrm{Nt}} \mathrm{PA}-1$

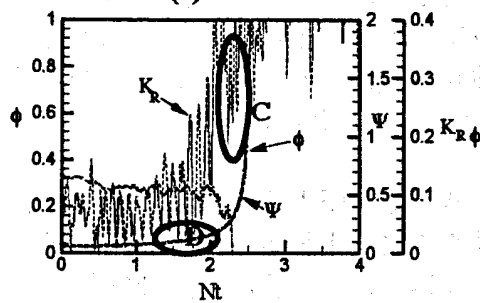

(c) PD-1

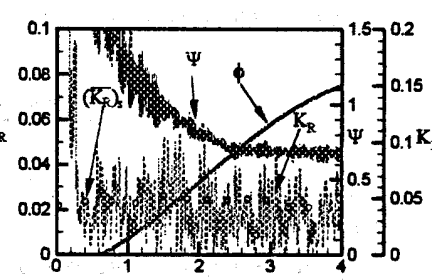

(b) ${ }^{\mathrm{Nt}}$ PA -2
Fig.7 Time histories of $\phi, \psi, K_{R}$

（4）変動流体力の周波数成分は $N\left(Z_{i} \pm 1\right)$ 成分が支配的であ ると予測できる。

ポンプ急始動・停止時の流体力実験から以下のことかかかか った.

（5）ポンプ急始動・停止時の過渡流体力は準定常值との間 に明確な食違いが生ずる。

（6）始動初期では流体力はその瞬間の準定常值よりも大き く，定常に至るまでに準定常值より小さくなる期間がある.

（7）停止初期では流体力は準定常值より大きくなり，回転 数が0に至るまでに準定常值より小さくなる期間がある.

（8）加速時間及ひ減速時間が短い場合，過渡流体力は準定 常値より大きくなる.

参考文献

(1) 張・王・塚本、機論 B, 68-671 (2002-7) ,2020.

(2) 張・王・塚本、機論，B，68-675 (2002-11),2997. 